Mukesh Kumar Sinha*, Biswa Ranjan Das, Namburi Eswara Prasad, Brian Kishore, Kamal Kumar

Defence Materials \& Stores Research \& Development Establishment, Defence Research \& Development Organization (DRDO), Kanpur, Uttar Pradesh, India
Scientific paper

ISSN 0351-9465, E-ISSN 2466-2585

UDC:620.197.6(n)

doi: doi:10.5937/ZasMat1802189K

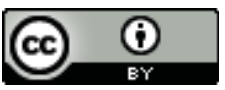

Zastita Materijala 59 (2)

$189-198(2018)$

\title{
Exploration of nanofibrous coated webs for chemical and biological protection
}

\begin{abstract}
Worldwide used Nuclear, Biological and Chemical (NBC) protective clothing has very limited protection against bacteria. Apart from this, NBC clothing has ample scope of improvements of some important features like comfort, better protection against CWA and weight reduction. The purpose of this research work is to establish process of integrating nanofibrous coated web with adsorbent layer of NBC clothing to achieve required biological protection and better chemical protection with reducing its weight. In this study, the developed activated carbon sphere (ACS) laminated structures are integrated with nanofibrous webs of Polyvinyl Alcohol (PVA). Design of the PVA integration process with adsorbent layer is strategically decided. PVA nanowebs of different morphological structures and coating densities $\left(0.03-0.61 \mathrm{~g} / \mathrm{m}^{2}\right)$ by latest nozzle-less nanospider technology are coated on polypropylene (PP) spun bonded nonwoven fabric. Then coated PP fabric is stitched at the boarder-line with adsorbent layer for formulating the composite layer. The various attributes and functional properties of PVA nanofibrous integrated absorbent layer is characterized by using FESEM, 1,3-Dichloropropane test (stimulant for mustard gas), durability test, pore size, air permeability and water vapour transmission rate. The reported research work showed that by integrating nanofibrous coated web layers into ACS laminated adsorbent layer of NBC clothing, it's now offering various functional properties like additional bacterial filtration and chemical protection at a lighter weight.
\end{abstract}

Keywords: adsorbent layer, biological, chemical, nanofibre, nanowebs, protection.

\section{INTRODUCTION}

In the textile industry, nanotechnology presents a significant commercial opportunity for technical textiles, especially for defence protective clothing applications. Nanofibres have gained attractiveness in research due to their morphological characteristics, high surface area, small and interlinked pore sizes and ultra-light-weight [1-4].

Defence protective fabrics are one of prime sector under technical textiles. Under the present war scenario, the main threats that forces face in missions is contaminated environment using chemical warfare agents (CWA) and biological agents. In general, most of chemical protective adsorbent layer is based on films/ membranes/ charcoal/foam/carbon particles etc [5-8].

\footnotetext{
*Corresponding author: Mukesh Kumar Sinha

E-mail: muk120in@yahoo.co.in

Paper received: 19.01.2018.

Paper accepted: 17.02.2018.

Paper is available on the website:

www.idk.org.rs/journal
}

There is evidence of development of chemical absorbent layer based on the ACS, but the developed products displayed many limitations like poor adhesion of ACS with substrate, low crushing strength of ACS, poor peeling strength of lamination and low durability due to frequent carbon shedding. In association with the above mentioned limitations, the composite layer was quite stiff, hence affects the desired comfort level. Therefore, mostly invented products are nondurable, limited bacterial protection, heavy weight, having poor adhesion/lamination with fabric, stiff (discomfort), low air permeability, poor porosity and water vapour transmission and these limitations are mainly due to filter /barrier layer either composed of knitted structures or thicker needle punched nonwoven fabrics. Therefore, research of nanofibrous coated web will be explored for fabricating a protective chemical and biological suit of lighter weight having numerous functional properties and adequate physiological wearing properties (heat stress/comfort).

Chemical warfare agent (CWA) is one of the most brutal weapons invented by mankind, which is 
categorised under the segment of weapons of mass destruction. Considering these facts, skin exposure to CWA is anticipated to kill human or any living organism. These CWA are mainly; chocking agent, blood agent, blister agent and nerve agent. This is used either in form of liquid, aerosol or vapour and powder. Few examples are; chocking agent - Phosgene (GC), blood agentHydrogen Cyanide (CN) \& Cyanogen Chloride (AC), blister agent-Sulfur Mustard (HD) \& Lewisite (L) and nerve agents- Tabun (GA), Soman (G), Sarin (GD) and sulfur-containing insecticides VX [6-8]. All these CWA mainly affect and attack the eyes and skin except chocking agent, which acts through respiratory system. Therefore, skin protection from these CWA is vital and foremost important in the warfare zone. Similarly, biological warfare (BW) involves the use of living organisms, which could be used as weapons. Classical biological warfare agents include bacteria, viruses, fungi, protozoa, and toxins from organic matter to damage/ kill humans, animals and plants [8].

Most of reported research works based on nano-fibre is carried out on conventional electrospinning set up using principle of disintegration theory of CWA [9-12]. Such set up consists of syringe and needle having limitations of practical application in terms of obtaining uniform quality webs, durability, lower specific strength and very lower throughput rate $(0.1-1.0 \mathrm{~mL} / \mathrm{h})$ and that is also for applying either in sound absorbing materials, aerosol and water filtration, wound healing and biomedical fabrics [2, 9-10,13-19].

Till date, not much attention has been paid to exploit nanowebs morphological properties to act as a barrier layer for chemical and biological filtration and that could be subsequently integrate with NBC adsorbent layer for creating defence protective fabrics of enhanced functionality at a lighter weight. DMSRDE initiated research to overcome the limitations and therefore, employed latest nozzleless spinning technique (Nanospider technology) to produce nanocoated fibrous webs. Nozzleless spinning technique consists of three major components for fulfilling the process: a high voltage power supply, a spinneret electrode and collecting electrode and detailed is explained in the experimental section. Advantages of such technology is; the electro-spun coating process facilitated fine and durable layer and very uniform deposition (coating) over fabric without affecting the substrate functional properties and also ample scope for integration of two high performance materials leading into coated composite functional structures. Nanospider technological research at DMSRDE, revealed that morphology and structures of nanofibrous coated web could be further tailored for a number of defence textile applications, such as; antimicrobial resistant, biological filtration, fire protection, thermal protection, chemical and biological protection etc. Use of nanofibrous coated webs belongs to a very new and emerged scenario. Integration of such material will help in the development of a completely new textile constructions and structures in the field of technical textiles. As extrapolation of such revolution, this work has established the concept of integrating nano-webs with Defence clothing to meet the current scenario requirement by enhancing bacterial filtration and chemical protection at a significantly reduced weight. Therefore, in this research work, an attempt has been made to exploit morphological properties (pore size between fibres) of coated webs to introduce the enhanced functional features. This research work demonstrated \& proven successfully the concept of integration of nanofibrous coated webs in NBC clothing. Nanowebs with much higher ratio of surface area/mass has offered higher comfort level in NBC clothing by improving air permeability and water vapour permeation rate.

Thus, the prime objective of this research is to study the effects of PVA nanofibrous coated web morphologies on bacterial filtration efficiency, protection against CWA (warfare stimulant), comfort performance and its durability. The study included the electrospinning of PVA and coating of nano-webs on PP nonwoven fabric of different morphological structure by varying coating densities and subsequently, integrated with NBC adsorbent layer. Field Emission Scanning Electron Micrograph (FESEM), Porometer, DCP (simulant mustard gas), air permeability, water vapour transmission and durability tests are employed to assess its functional and morphological properties. Results revealed that nano-integrated NBC adsorbent functional structure is highly durable, possessing bacterial filtration properties (BFE $90.53 \%$ ) and also noticed weight reduction $25 \%$ by altering the pore sizes. These created durable coated nano-fibrous webs are exploited for protection against bacterial and CWA at a reduced weight and leading to advanced version of chemical and bacterial filtration protective clothing.

\section{EXPERIMENTAL}

This current perspective research is related to combining and integration of nano-fibrous coated webs with NBC ACS laminated fabrics. The experimental flow diagram of nano-fibrous integrated with adsorbent layer is displaying its various layers/constituents as shown in Figure 1 [68, 20]. 


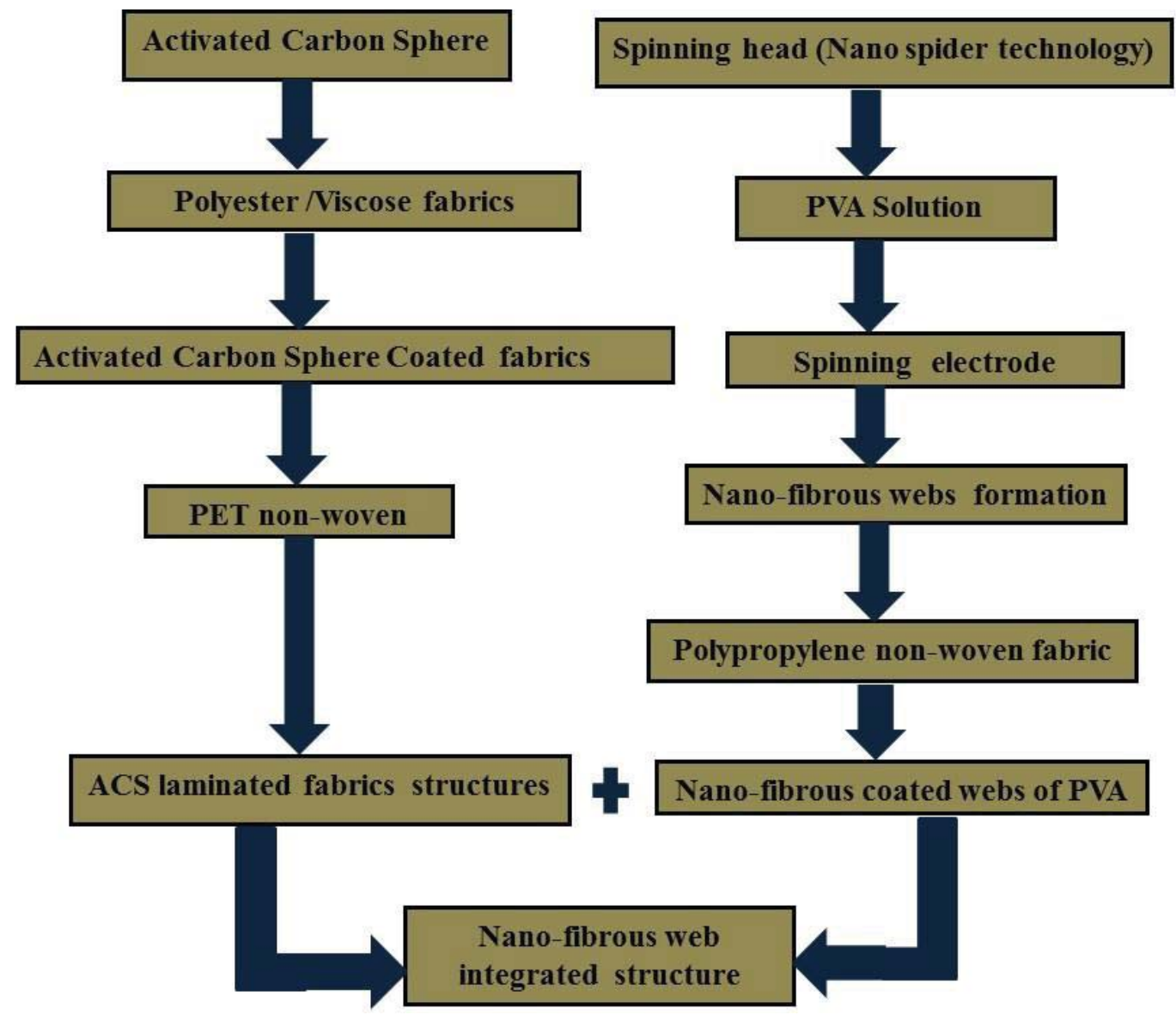

Figure 1. Schematic flow diagram of Nano-fibrous coated webs and ACS laminated manufacturing fabric process

Slika 1. Shematski dijagram toka procesa presvljačenja nano-vlaknastih mreža i ACS laminiranog materijala

\subsection{Materials}

Anti-stat PP spun-bonded $\left(30 \mathrm{~g} / \mathrm{m}^{2}\right)$ non-woven fabric having a surface resistivity in the order of $10^{10} \Omega \cdot \mathrm{cm}$ is used as a coating substrate. The electro-spun nano-fibres coated web is integrated with ACS laminated adsorbent layer having range $300-450 \mathrm{~g} / \mathrm{m}^{2}$. The composite layer is studied for evaluation of different functional features.

\subsection{Sample preparation}

Polyvinyl Alcohol (PVA) of hydrolysed grade is dissolved in distilled water (solution concentration $12 \% \mathrm{w} / \mathrm{v}$ ) at $80^{\circ} \mathrm{C}$ with magnetic stirring for at least 3-4 hours for obtaining the solution. PVA solution is electro-spun through Nanospider machine for preparation of webs in accordance with the experimental trials as mentioned in Table 1 . The prepared coated webs of different morphology are air dried for $20 \mathrm{~min}$ to remove residual water molecules.
Table 1. Experimental and operational parameters of Nano spider process

Tabela 1. Eksperimentalni i operativni parametri procesa "Nanopauka"

\begin{tabular}{|c|c|c|c|}
\hline $\begin{array}{l}\text { Exp. } \\
\text { Number }\end{array}$ & $\begin{array}{l}\text { Varied } \\
\text { Collecting } \\
\text { electrode } \\
\text { speed } \\
\text { (m/min.) }\end{array}$ & $\begin{array}{c}\text { Identical } \\
\text { operating } \\
\text { parameters }\end{array}$ & $\begin{array}{l}\text { Coating } \\
\text { density } \\
\left(\mathrm{g} / \mathrm{m}^{2}\right)\end{array}$ \\
\hline 1 & 0.25 & \multirow{6}{*}{$\begin{array}{c}\text { Voltage }-60 \mathrm{KV} \\
\text { Distance } \\
\text { between two } \\
\text { electrodes } \\
-135 \mathrm{~mm} \\
\text { Rotation of } \\
\text { spinning } \\
\text { electrode } \\
-7 \mathrm{rpm}\end{array}$} & 0.61 \\
\hline 2 & 0.51 & & 0.43 \\
\hline 3 & 0.84 & & 0.22 \\
\hline 4 & 1.06 & & 0.13 \\
\hline 5 & 1.23 & & 0.05 \\
\hline 6 & 1.98 & & 0.03 \\
\hline
\end{tabular}




\subsection{Electrospinning process}

The process of coating PVA nanoweb on polypropylene fabric is through nozzleless coating technique, where a coating of nanofibre is carried out by latest Nano-spider technology. The coating process is based on potential difference between spinning electrode (positively charged ions) and collecting electrode (negatively charged ions) [21]. Spinning electrode is immersed in the polymer solution contained in spinning head. Higher potential difference between these electrodes leads to extrusion of polymer solution (PVA) from spinning electrode in the form of conical nanofibrous web and it is deposited over the moving PP fabric. Rotations of the spinning electrode offer a constant source of specified solution quantity to be utilized for extrusion. The potential difference, distance between electrodes and PP fabric moving speed decide the density $\left(\mathrm{g} / \mathrm{m}^{2}\right)$ and morphology of coated PVA nanofibrous web. Once it was determined the ideal condition for fabricating web, thereafter under identical conditions electro-coating process was done by varying collector speed. The operating parameters are specified in the Table 2.

Table 2. Effect of morphological structures of PVA coated nano fibrous web on bacterial filtration efficiency (\% BFE)

Tabela 2. Efekat morfoloških struktura nano vlaknastih mreža obloženih PVA na efikasnost bakterijske zaštite (\% BFE)

\begin{tabular}{|c|c|c|c|c|}
\hline Sample & Coating density $\left(\mathrm{g} / \mathrm{m}^{2}\right)$ & Mean pore size $(\mu \mathrm{m})$ & $\%$ BFE & Mean Air Permeability $\left(\mathrm{cc}^{3} / \mathrm{cm}^{2} / \mathrm{s}\right)$ \\
\hline A & 0.61 & 7.8 & 94.82 & 18.6 \\
\hline B & 0.43 & 9.2 & 92.53 & 32.8 \\
\hline C & 0.22 & 10.6 & 88.86 & 36.7 \\
\hline D & 0.13 & 14.5 & 61.60 & 40.2 \\
\hline E & 0.05 & 20.1 & 43.40 & 50.1 \\
\hline F & 0.03 & 25.8 & 40.10 & 70.1 \\
\hline
\end{tabular}

\subsection{Characterisation}

\subsubsection{Surface morphology}

Morphology of electro-spun fibre is examined by using the Field Emission Scanning Electron Microscopy (Zeiss EV 050). Diameters of nanofibres are estimated by Image $\mathrm{J}$ software using the captured FESEM images. The average fibre diameter is determined from 30 measurements of random fibres taken from different areas of the scanned images.

\subsubsection{Water vapour transmission}

Breathability (comfort) of adsorbent layer is evaluated in accordance with ASTM E 96, Procedure B (upright cup method). Adsorbent fabrics are placed with coated side facing the water in cup and placed under conditioning chamber $12 \pm 1^{\circ} \mathrm{C}$ (50\% relative humidity) for overnight. The water vapour transmission rate (WVTR) is calculated using the following formula $G / t / A$, where $\mathrm{G}=$ weight change $(\mathrm{g}), \mathrm{t}=$ time during which $\mathrm{G}$ occurred, and $A=$ test area $\left(\mathrm{m}^{2}\right)$ expressed in grams $/ \mathrm{m}^{2} / 24$ hours.

\subsubsection{Air permeability}

Air permeability of electro-spun coated webs incorporated functional fabric structures is measured using a Frazier air permeability testing instrument and as per British standard test method no BS EN ISO 9237:1995 [22]. Rate of flow of air through a given area is measured when there is a pressure drop of $10 \mathrm{~mm}$ head of water across the web specimen. Ten readings from different parts of the coated webs are recorded in terms of $\mathrm{cm}^{3} / \mathrm{cm}^{2} / \mathrm{s}$ at $10 \mathrm{~mm}$ water head to calculate the mean value.

\subsubsection{Durability of Nanofibres integrated functional structures}

(a) Flexing test- Sample specimens are subjected to flexing by De-Mattia method. The apparatus is set in motion for 500 cycles of flexing. After flexing cycles are completed, test specimen is removed from the apparatus and then conditioned and finally, microscopic examination is conducted to observe any peel-off or deformation in nano-web structures after the flexing cycles.

(b) Abrasion resistance- It is conducted by using a Martindale abrasion tester (ASTM F392-93) to assess the durability and adhesion of electrospun coated webs integrated functional fabric structures. Samples are subjected to run a batch of 3000 movements and observed, if any peel-off, deformation on surface, broken fibres or abraded surface or hole in the webs after abrasion treatment. 


\subsubsection{Bacterial filtration}

Nano-web incorporated functional structures are clamped between a six stage cascade impactor and an aerosol chamber at a distance of $15 \mathrm{~cm}$. Bacterial (Staphylococcus Aureus- ATCC6538) aerosol is generated in chamber using the 10 micron nebuliser assembly. The aerosol is drawn through test material using a vacuum attached to cascade impactor. Positive control samples collected aerosol with no test specimen to determine the up-stream aerosol counts. The ratio of up-stream to downstream is reported as percentage Bacterial Filtration Efficiency (\% BFE). Medium used to generate bacteria is Soyabean Casein Digest Agar plates. Bacteria colonies are counted the after 24 hours of incubation at $37^{\circ} \mathrm{C}$.

\subsubsection{Dichloropropane (DCP) penetration test}

DCP test is an established test protocol for services to assess the effectiveness of NBC defence protective fabrics against vapours of sulphur mustard warfare agents. DCP and DMMP are regularly measured as simulants of mustard gas [22]. DCP test of functional fabric structures is

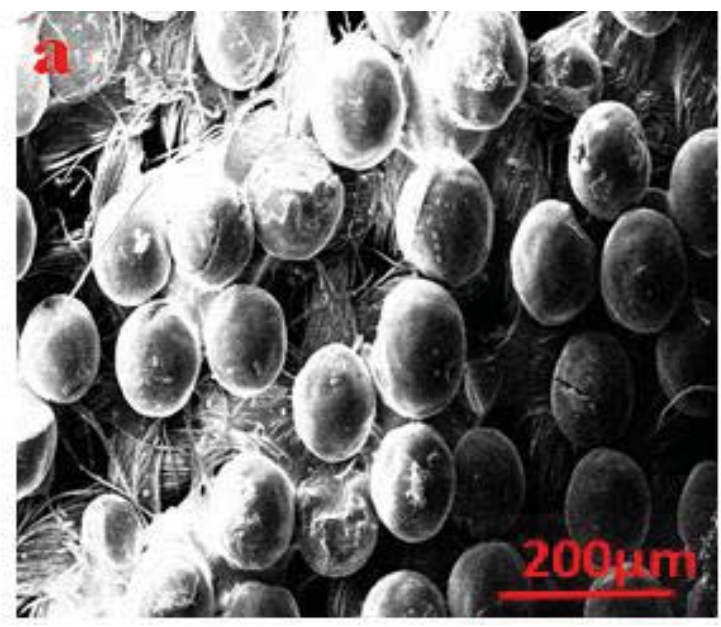

measured using a flame ionization detector (FID) unit and the method referred in British Specification No. UK/SC/3346G. The results are recoded in terms of time taken to pass vapour penetration rate of $1 \mu \mathrm{g} / \mathrm{min}$ of 1,3 dichloropropane (DCP) through fabric and mean values of five readings is presented.

\subsubsection{Capillary liquid expulsion porometry}

Pore size measurements are made with the Model POROMETER 3G win 10.10 Series automated capillary flow porometer manufactured by Quantachrome Instruments, Inc. Pore sizes are measured by saturating the porous material with a wetting soap liquid.

\section{RESULTS AND DISCUSSION}

\subsection{Webs Morphological and protective behaviours}

It was necessary to study morphology of ACS adhered laminated fabrics (works on adsorption of CWA principle), before integrating the web into adsorbent layer. Surface morphology of adsorbent layer of $356 \mathrm{~g} / \mathrm{m}^{2}$ (lower weight) and $403 \mathrm{~g} / \mathrm{m}^{2}$ (higher weight), are depicted in Figure 2.

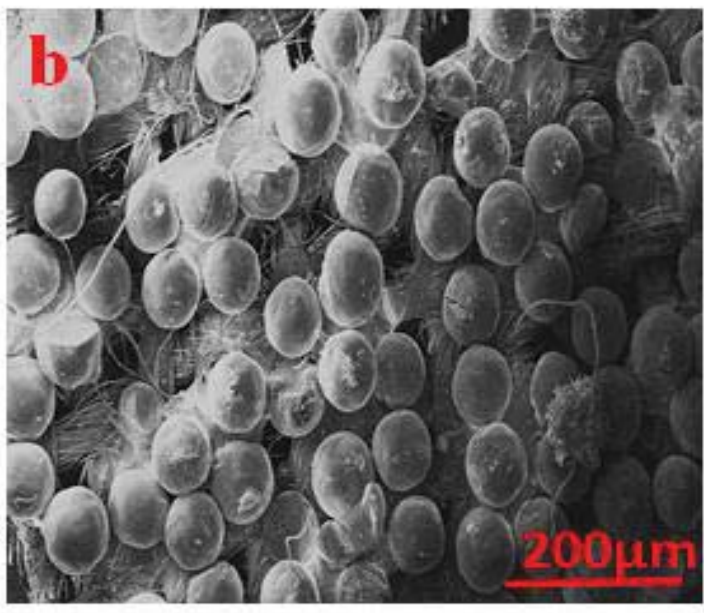

Figure 2. FESEM images of ACS adhered woven fabric of different: (a) $356 \mathrm{~g} / \mathrm{m}^{2}$ loose packing of ACS and (b) $403 \mathrm{~g} / \mathrm{m}^{2}$ dense packing of ACS

Slika 2. FESEM slike ACS spajanja tkanina različitih težina: (a) $356 \mathrm{~g} / \mathrm{m} 2$ labavo pakovanje ACS-a i (b) $403 \mathrm{~g} / \mathrm{m}^{2}$ gusto pakovanja ACS-a.

NBC adsorbent layer is working on adsorption of CWA by ACS to protect skin. It can be seen that even with high loading of ACS $210 \mathrm{~g} / \mathrm{m}^{2}$ estimated average pore size is $\sim 80.6 \mu \mathrm{m}$, which may allow to penetrate CWA through such higher pore size after saturation. It has other objective that, such large pore size is kept for permeability of air and water vapour transmission for achieving desired comfort level in NBC adsorbent layer. Therefore, nanofibre web's morphology could be a vital element to balance these functional properties. Figure 3 shows FESEM microphotography of electro-spun nanofibrous coated web of PVA on PP nonwoven fabrics of different morphological structures by varying coating speed and at the same time, other parameters are kept constant. It is evident from Figure 3 (a-f) that morphology of electro-spun web is greatly influenced by coating density. 

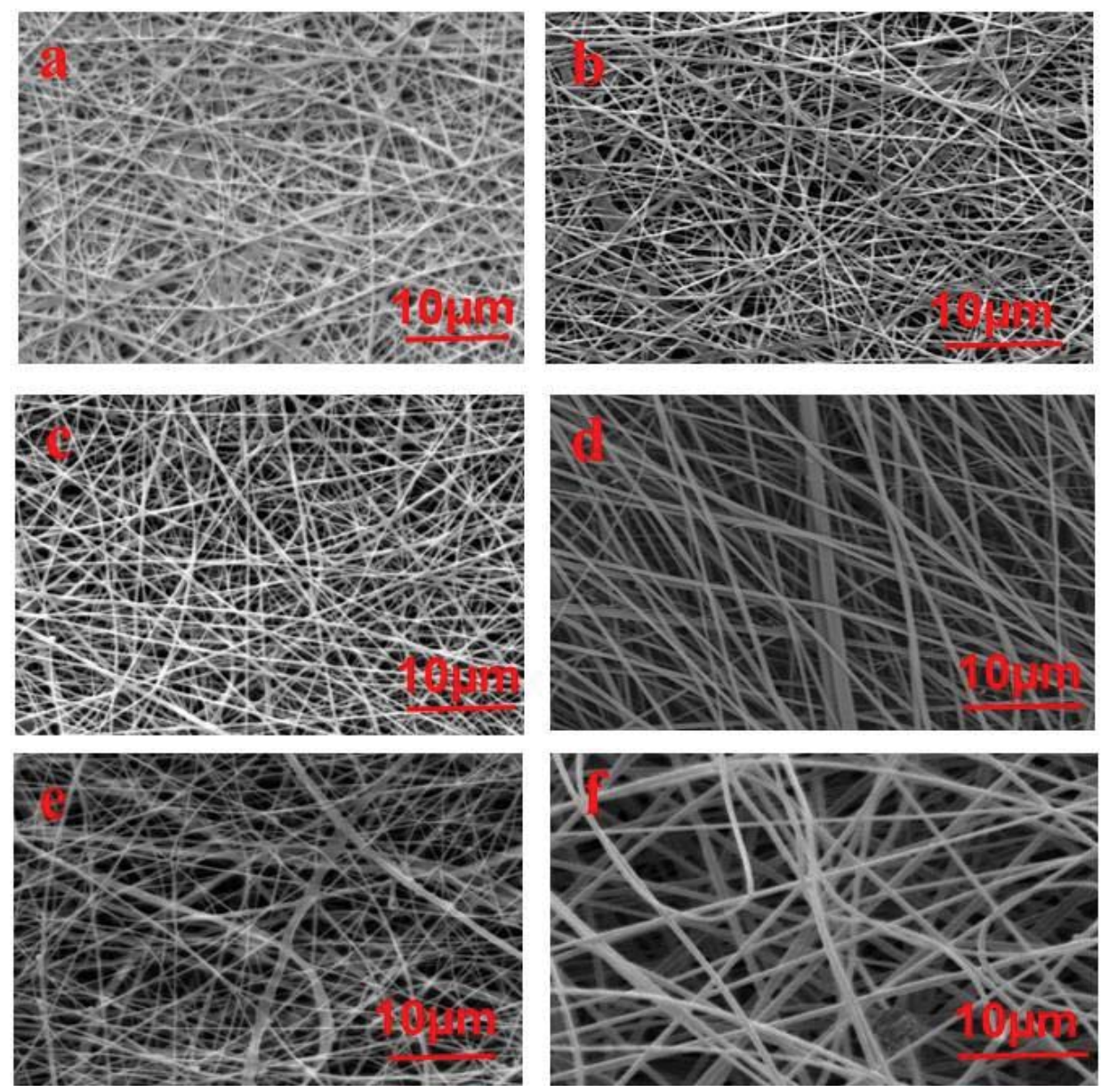

Figure 3. PVA Electro-spun nano-fibres of different morphology (coating densities) for filtration media (a: 0.61, b: 0.43, c: 0.22, d: 0.13, e: 0.05 and $f: 0.03 \mathrm{~g} / \mathrm{m}^{2}$ )

Slika 3. PVA nano-vlakana različite morfologije (gustine premaza) za filtracione medije (a: 0.61, b: 0.43, c: $0.22, d: 0.13$, e: 0.05 and $f: 0.03 \mathrm{~g} / \mathrm{m}^{2}$ )

Figure 3 revealed that as coating density increased, the pore size is decreased (Figure 3aweb density is higher as compared to Figure $3 \mathrm{f}$ ). This demonstrates that pore size between fibres is become extremely important for filtering or separating chemical or bacteria, either as a blocker or absorbent media. Comfort characterization in terms of functional properties breathability and water vapour transmission is presented in Table 3. The results clearly showed that, morphology of coated webs determined porosity between fibres and subsequently, decided the comfort and filtration. However, these two functional properties are contradictory in nature. Therefore, a judicious balance should be made between filtration and comfort level to optimize the product.

Table 3. Chemical protection evaluation of composite layer

Tabela 3. Procena hemijske zaštite kompozitnog sloja

\begin{tabular}{|c|c|c|c|c|}
\hline Sample (g/m2) & $\begin{array}{c}\text { Nano coated layer } \\
\left(\mathrm{g} / \mathrm{m}^{2}\right)\end{array}$ & $\begin{array}{c}\text { Observed DCP } \\
(\mathrm{min})\end{array}$ & $\begin{array}{c}\text { Specified DCP } \\
(\mathrm{min})\end{array}$ & $\begin{array}{c}\text { Water vapor transmission } \\
\left(\mathrm{g} / \mathrm{m}^{2} / 24 \mathrm{~h}\right)\end{array}$ \\
\hline AL (356) Control & - & 110 & 150 & 450.65 \\
\hline AL (356) + NFCW & 21.02 & 250 & 150 & 609.25 \\
\hline AL (403) Control & - & 290 & 150 & 400.01 \\
\hline AL (403) + NFCW & 21.02 & 370 & 150 & 550.76 \\
\hline
\end{tabular}

AL - Adsorbent layer \& NFCW- Nano-fibrous coated webs 
Table 3 shows that coating density of $0.43 \mathrm{~g} / \mathrm{m}^{2}$ is showing and also matching standard requirements for air permeability and water vapour transmission with $92.53 \%$ bacterial filtration.

This coated web layer is chosen and integrated with NBC adsorbent layer of $356 \mathrm{~g} / \mathrm{m}^{2}$ (lower weight) and $403 \mathrm{~g} / \mathrm{m}^{2}$ (higher weight) for DCP test. Result showed in Table 3 that even lower weight of integrated functional adsorbent layer $\left(356 \mathrm{~g} / \mathrm{m}^{2}\right)$ has achieved the standard specified value of DCP with enhanced water vapour transmission. This may be due to two factors; (1) nano-fibrous coated webs has blocked the penetration of chemical due to its pore size $\sim 9.2 \mu \mathrm{m}$ and acting as a blocker for sub-micron sized simulant (size 40-50 $\mu \mathrm{m}$ ). The other factor is: (2) PVA is highly hydroscopic in nature and chemical molecules get absorbed on the surface of webs and by virtue of which, penetration gets delayed to adsorbent layer and thus, resulted in high DCP penetration time. Considering this fact, nano-coated web layers are integrated into adsorbent functional layer, which does not allow to penetrate CWA and bacteria but permeable to air and water vapour. So, it is acting as a semi permeable membrane due to; small pore

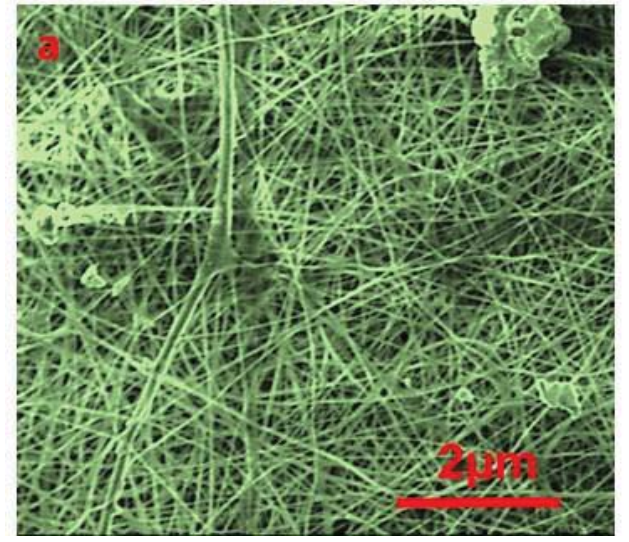

size and large number of pores between fibres per unit area (high porosity), which has resulted into enhanced comfort. This is evident and matching with information received from captured FESEM images (Figures 3 a-f). Further, the chemical barrier properties are confirmed and evident by spotting 20 micron litre sulphur mutated simulant on the web and FESEM images has been captured immediately. Figure 4 clearly demonstrated that sulphur mutated simulant chemical molecules is adhered onto surface of the web and therefore, web is acting as a barrier layer for CWA sulphur mustard gas. On the other hand, air permeability, water vapour, and bacteria and chemical filtration results of functional integrated layer showed agreement and correlation with those obtained by pore size and morphological measurements [2431]. Nanoweb morphology act as a barrier layer is in close agreement with previously reported work for various other applications [32-39]. Finally, nanofibre integration leads to introduction of bacterial filtration functional properties and enhanced chemical filtration without affecting comfort properties and also reduced the weight of adsorbent layer.

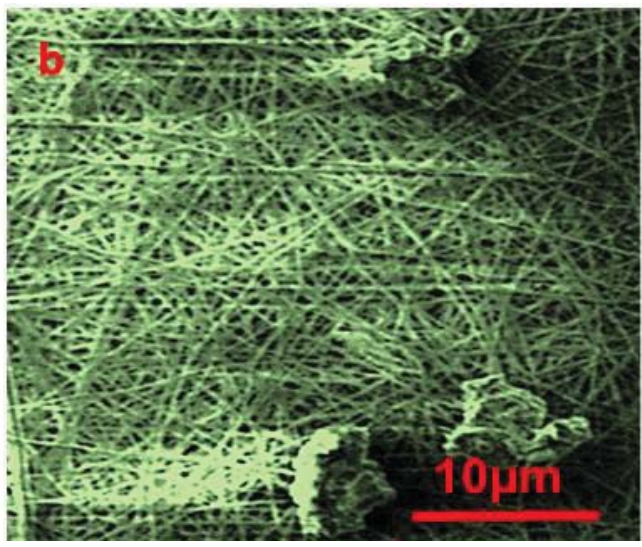

Figure 4. FESEM images of mustard simulant adhered webs: (a) $2 \mu \mathrm{m}$ and (b) $10 \mu \mathrm{m}$

Slika 4. FESEM slike: (a) $2 \mu \mathrm{m}$ and (b) $10 \mu \mathrm{m}$

\subsection{Durable nano-fibres integrated adsorbent layer}

To convert nanoweb into integrated functional layer for filtration applications, durability of web is one of most important parameters. In order to assess the ability of nanofibre electro spun webs coated on non-woven substrate to withstand repetitive strain- De- mattia (flexing test) and Martindale abrasion tester techniques are employed. Nanofibrous integrated adsorbent layer is subjected to flexing (500 Cycles) and abrasion tester (3000 Cycles). After subjected tests (flexing and abrasion), the assessment of webs is conducted under optical microscopic examination and Surface optical profilometer and topography analysis (quantitative analysis) by separating nano- web layers from functional layers. Rubbed samples and their surface macro morphologies are observed in photographic images as shown in Figure 5.

It is observed that the nano-fibre layer is not damaged even after 3000 cycles and therefore, it confirmed that the prepared nano-fibre layer has higher level of durability. Furthermore, to supplement this result, Surface optical profilometer is used to evaluate the surface roughness before and after 3000 rubbing cycles of separated webs. The topography (roughness) plots of the nanofibrous webs samples (before and after rubbing cycles) are shown in Figure 6. 

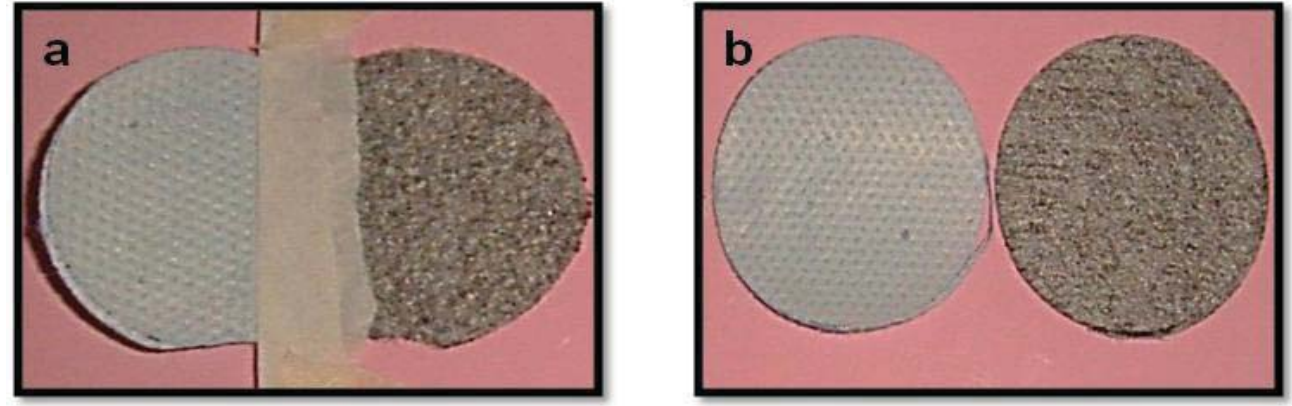

Figure 5. Macroscopic photographic imaging of PVA webs separated from functional adsorbent layer: (a) before and (b) after abrasion

Slika 5. Makroskopska fotografska slika PVA mreža odvojena od funkcionalnog sloja adsorbenta: (a) pre i (b) nakon abrazije
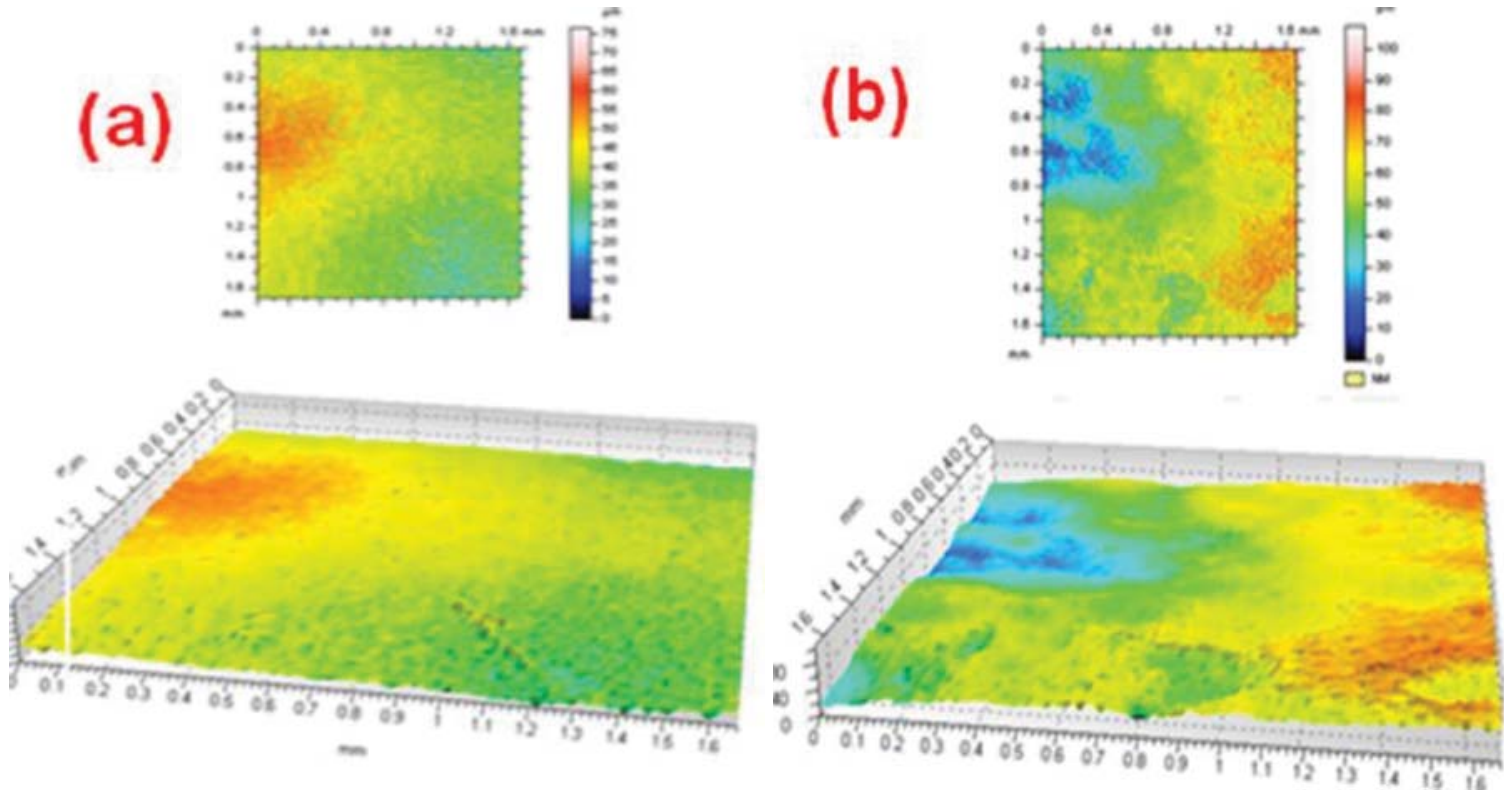

Figure 6. Effect of abrasion on the surface of PVA webs as depicted by surface optical profilometer:

(a) before abrasion and (b) after abrasion

Slika 6. Efekat abrazije na površinu PVA mreža prikazano površinskim optičkim profilometrom:

(a) pre abrazije i (b) nakon abrazije

Comparing the topography plots, it is observed that no significant change is found after repetitive and rugged rubbing of webs. The measured values of Root Mean Square Deviation of the roughness profile are 7.66 and $6.92 \mu \mathrm{m}$ for before and after rubbing of webs respectively. Hence, it is confirmed that after rubbing of nano-fibre; not any- surface damages, cracking, deformation and fibres peel-off has occurred. The durability of webs may be due to; (1) the addition of cross linking agent, which is yielded in improved dimensional stability, abrasion, flexing, peel-off and mechanical properties of the webs and (2) physical entrapping of nanofibres into porous structures of spun-bonded non-woven fabric and this durability of web is in close agreement with previously reported works [5, 39].

\section{CONCLUSIONS}

ACS laminated fabric is the most important component of Nuclear, Biological and Chemical (NBC) protective suit for offering chemical protection. Hence, futuristic approach of integration of nano-fibrous webs is carried out along with this component to enhance chemical protection and biological filtration at reduced weight. PVA nanoweb coated on polypropylene non-woven fabrics are successfully integrated with ACS laminated fabric for protection against CWA and bacteria. The biological filtration and chemical protection are evaluated and optimized nano-web density (0.43 $\mathrm{g} / \mathrm{m}^{2}$ ) is offering highest biological filtration and chemical protection along with meeting the 
specified air permeability and water vapour transmission for defence protective fabrics. Result also revealed that, even after 500 cycles of flexing, no crack or holes or peel-off or deformation is observed and smooth surface has been detected by microscopic examination. The result of abrasion tester showed that even after 3000 cycles, weight loss is found to be negligible. Therefore, it is clearly indicated that the research work is of practical use and durable layer webs could be integrated with functional fabrics. The durable layered structures are may be due to better physical adhesion of nanofibres with PP non-woven fabric. This outstanding nano-research carried out will facilitate in the development of next generation NBC suit. Thus, these nanofibrous coated membranes have shown potential for using as a layer for developing futuristic NBC adsorbent layer with enhanced comfort, lowering weight $\sim 25 \%$ with additional bacterial filtration properties to meet defence protective light weight fabric requirements. This study could be further recommended for safe guarding the PVA coated structures by virtue of laminating with breathable films and so that, whole functional structure could be used for repeated washes. This state of art electrospinning coating technology could be exploited for mass production.

\section{REFERENCES}

[1] J.Venugopal, S.Ramakrishna (2005) Applications of polymer nanofibers in biomedicine and biotechnology, Applied Biochemistry and Biotechnology, 125, 147-157.

[2] Z.M.Huang, Y.Z.Zhang, M.Kotaki, S.Ramakrishna (2003) A review on polymer nanofibres by electrospinning and their applications in nanocomposites, Composites Science and Technology, 63, 2223-2253.

[3] Y.Liu, J.H.He, J.Y.Yu, H.M.Zeng (2008) Controlling numbers and sizes of beads in electrospun nanofibres, Polymer International, 57, 632-636.

[4] S.Peng, G.Jin, L.Li, K.Li, M.Srinivasan, S.Ramakrishna, J.Chen (2016) Multi-functional electrospun nanofibres for advances in tissue regeneration, energy conversion \& storage, and water treatment, Chemical Society Reviews, 45, 1225-1241.

[5] J.D.Langley, J.R.Cole, A.J.Terrell (2010) Selectively Permeable Chemical Protective Films and Composite Fabrics. USA Patent, No. 20100251466 A1.

[6] M.Boopathi, B.Singh, R.Vijayaraghavan (2008) A review on NBC body protective clothing, The Open Textile Journal, 1, 1-8.

[7] R.Karkalić, V.Maslak, A.Nikolić, M.Kostić, D. Jovanović, Ž.Senić, Z.Veliçković, (2015) Application of permeable materials for CBRN protective equipment, Zaštita Materijala, 56, 239-241.

[8] K.Ganesan, S.K.Raza, R.Vijayaraghavan (2010) Chemical warfare agents, Journal of Pharmacy \& Bio Allied Sciences, 2, 166-178.
[9] E.Khalil (2015) A technical overview on protective clothing against chemical hazards, AASCIT Journal of Chemistry, 2, 67-76.

[10] G.Thilagavathi, A.S.M.Raja, T.Kannaian (2008) Nanotechnology and protective clothing for defence personnel, Defence Science Journal, 58, 451-458.

[11] R.Ramaseshan, S.Sundarrajan Y.Liu, R.S.Barhate, N.L.Lala, S.Ramakrishna (2006) Functionalized polymer nanofibre membranes for protection from chemical warfare stimulants, Nanotechnology, 17, 2947-2953.

[12] R.Ramaseshan, S.Ramakrishna (2007) Zinc titanate nanofibres for the detoxification of chemical warfare simulants, Journal of the American Ceramic Society, 90, 1836-1842.

[13] M.Zafar, S.Najeeb, Z.Khurshid, M.Vazirzadeh, S.Zohaib, B.Najeeb, F.Sefat (2016) Potential of electrospun nanofibres for biomedical and dental applications, Materials, 9, 73-93.

[14] A.Rajak, A.Sawitri, M.M.Munir, F.I.Khairurrija (2015) Synthesis of electrospun nanofibres membrane and its optimization for aerosol filter application, KnE Engineering, 2016, 1-7.

[15] V.Jacobs, A.Patanaik, R.D.Anandjiwala (2010) Electrospun chitosan nanofibre membranes for antimicrobial application: Role of electrospinning processing parameters, European Cells and Materials, 19, 4-12.

[16] R.Nawalakhe, Q.Shi, N.Vitchuli, J.Noar, J.M. Caldwell, F.Breidt, M.A.Bourham, X.Zhang, M.G.McCord (2013) Novel atmospheric plasma enhanced chitosan nanofibre/gauze composite wound dressings, Journal of Applied Polymer Science, 129, 916-923.

[17] J.Alba, R.D.Rey, L.Berto, C.Hervias (2012) Use of textile nanofibres to improve the sound absorption coefficient of drilled panels for acoustic applications, April 23-27, Nantes Conference, Proceedings of the Acoustics, Nantes, France, p.303-307.

[18] M.Gouda, A.A.Hebeish, A.I.Aljafari (2014) Synthesis and characterization of novel drug delivery system based on cellulose acetate electrospun nanofibre mats, Journal of Industrial Textiles, 43, 319-329.

[19] D.Lubasova, A.Netravali, J.Parkerand, B.Ingel (2014) Bacterial filtration efficiency of green soy protein based nanofibre air filter, Journal of Nanoscience and Nanotechnology, 14, 4891-4898.

[20] D.Lal, V.S.Tripathi, G.N.Mathur (2009) A Process for the Production of Chemical Protective Fabric, Indian Patent, No. 237276.

[21] M. Kurečič, M.S. Smole (2013) Electrospinning: Nanofibre production method, Tekstilec, 56, 4-12.

[22] BS EN ISO 9237 (1995) Method for Determination of Permeability of Fabrics to Air, British Standards.

[23] A.A. Tomchenko, G.P.Harmer, B.T.Marquis (2005) Detection of chemical warfare agents using nanostructured metal oxide sensors, Sensors and Actuators B, 108, 41-55.

[24] M.Krifa, W.Yuan (2016) Morphology and pore size distribution of electrospun and centrifugal force spun nylon 6 nanofibre membranes, Textile Research Journal, 86, 1294-1306.

[25] M.Ziabari, V.Mottaghitalab, A.K.Haghi (2008) Evaluation of electrospun nanofibre pore structure 
parameters, Korean Journal of Chemical Engineering, 25, 923-932.

[26] J.R.Kovacina, A.S.Weiss (2011) Increasing the pore size of electrospun scaffolds, Tissue Engineering Part B Reviews, 17, 365-372.

[27] M.W.Frey, L.Li (2007) Electrospinning and porosity measurements of nylon-6/ poly (ethylene oxide) blended nonwovens, Journal of Engineered Fibres and Fabrics, 2, 31-37.

[28] S.S.Sreedhara, N.R.Tata (2013) A novel method for measurement of porosity in nanofibre mat using pycnometer in filtration, Journal of Engineered Fibres and Fabrics, 8, 132-137.

[29] J.Yao, C.W.M.Bastiaansen, T.Peijs (2014) High strength and high modulus electrospun nanofibers, Fibers, 2, 158-187.

[30] M.Yanilmaz, M.Diricana, X.Zhang (2014) Evaluation of electrospun $\mathrm{SiO}_{2}$ /nylon 6,6 nanofibre membranes as a thermally-stable separator for lithium-ion batteries, Electrochimica Acta, 133, 501508.

[31] M.A.Hassan, B.Y.Yeom, A.Wilkie, B.Pourdeyhimi, S.A.Khan (2013) Fabrication of nanofibre meltblown membranes and their filtration properties, Journal of Membrane Science, 427, 336-344.

[32] D.Lubasová, A.Netraval, J.Parker, B.Ingel (2012) Innovative laboratory technique for testing of bacterial filtration efficiency of nanofibre-based filters, Oct 23-23, Nanocon Conference, Proceedings, Brno, Czech Republic.

[33] N.R.Dhineshbabu, G.Karunakaran, R.Suriyaprabha, P.Manivasakan, V.Rajendran (2014) Electrospun
$\mathrm{MgO}$ /nylon 6 hybrid nanofibres for protective clothing, Nano-Micro Letters, 6, 46-54.

[34] S.S.Nair, J.Zhu, Y.Deng, A.J.Ragauskas (2014) High performance green barriers based on nanocellulose, Sustainable Chemical Processes, 2, 1-7.

[35] M.Faccini, C.Vaquero, D.Amantia (2012) Development of protective clothing against nanoparticle based on electrospun nanofibres, Journal of Nanomaterials, 20, 1-9.

[36] S.Lee, S.K.Obendorf (2007) Use of electrospun nanofibre web for protective textile materials as barriers to liquid penetration, Textile Research Journal, 77, 696-702.

[37] P.Chandrasekhar, P.Pirgov, B.J.Zay, D.Lawrence, S.Morefield, T.L.Rittenhouse, S.G.Clementi, Q.Truong, R.R.Greene (2013) Electroosmotic water vapour transport across novel, smart, functionalized conducting polymer microporous membranes in active mode at very high rates, with concomitant chemical warfare (CW) agent blocking, Advances in Materials Physics and Chemistry, 3, 217-237.

[38] P.I.Dolez, T.Vu-Khanh (2009) Recent developments and needs in materials used for personal protective equipment and their testing, International Journal of Occupational Safety and Ergonomics, 15, 347-362.

[39] Q.Shi, N.Vitchuli, J.Nowak, S.Jiang, J.M.Caldwell, F.Breidt, M.Bourham, X.Zhang, M.McCord (2013) Multifunctional and durable nanofibre-fabric-layered composite for protective application, Journal of Applied Polymer Science, 128, 1219-1226.

\title{
IZVOD
}

\section{ISTRAŽIVANJE NANOFIBRIRANIH OBLOŽENIH TRAKA ZA HEMIJSKU I BIOLOŠKU ZAŠTITU}

\begin{abstract}
Zaštitna odeća od nuklearne, biološke i hemijske (NBH) zaštite širom sveta ima veoma ograničenu zaštitu od bakterija. Osim toga, odeća NBH ima dosta poboljšanja u nekim važnim osobinama kao što su udobnost, bolja zaštita od CVA i smanjenje težine. Svrha ovog istraživačkog rada je uspostavljanje procesa integrisanja nanofibrirane obložene mreže sa adsorbentnim slojem NBH odeće radi postizanja potrebne biološke $i$ hemijske zaštite $i$ smanjivanje njegove težine.

U ovom istraživanju razvijena je laminirana struktura aktivne ugljenične sfere (ACS) integrisana sa nanofibriranim mrežama od polivinil alkohola (PVA). Dizajn procesa integracije PVA sa adsorbentnim slojem strateški je rešen.

PVA različitih morfoloških struktura i gustina premaza $\left(0,03-0,61 \mathrm{~g} / \mathrm{m}^{2}\right)$ najnovijom tehnologijom "pauka" bez nanosa, su naneti na polipropilen (PP) vezane netkane tkanine. Tako obložena PP tkanina je spojena na graničnoj liniji sa slojem adsorbenta na kompozitnom sloju. Različiti atributi $i$ funkcionalne osobine PVA nanofibroznog integrisanog upijajućeg sloja karakterišu upotrebom FESEM-a, testa 1,3-Dihloropropana (stimulans za iperit), testa izdržljivosti, veličine pora, prozračnosti vazduha i brzine prenosa vodene pare. Navedena istraživanja su pokazala da su integracijom nanofibriranih slojeva u sloj adsorbentnih slojeva NBH odeće, povećane razne funkcionalne osobine kao što su dodatna bakterijska i hemijska zaštita i smanjenje težini odela.

Ključne reči: sloj adsorbenta, biološka i hemijska zaštita, nanofiber.
\end{abstract}

Naučni rad

Rad primljen: 19. 01. 2018.

Rad prihvaćen: 17. 02. 2018.

Rad je dostupan na sajtu: www.idk.org.rs/casopis

(C) 2018 Authors. Published by Engineering Society for Corrosion. This article is an open access article distributed under the terms and conditions of the Creative Commons Attribution 4.0 International license (https://creativecommons.org/licenses/by/4.0/) 